\title{
Cartographic Perspectives
}

\author{
Journal of the \\ North American Cartographic \\ Information Society
}

SPECIAL DIGITAL ISSUE

\section{IN THIS ISSUE}

\section{LETTER FROM THE GUEST EDITOR}

Tanya Andersen Buckingham

\section{FEATURED ARTICLES}

Freeing CP: GIS\&T and NACIS in the Open Educational Resources Movement David DiBiase

Extending the Google Maps API for Event Animation Mashups (with Tutorial)

Robert E. Roth, Kevin S. Ross

Cartography 2.0: For People Who Make Interactive Maps

Mark Harrower, Anthony C. Robinson, Robert Roth, Ben Sheesely

Natural Earth Vector

Nathaniel Vaughn Kelso, Tom Patterson

When is it Too Late to Find a Cartographer?

Charlie Frye

Cartographies of Participation: How the Changing Natures of Cartography Has Opened

Community and Cartographer Collaboration

William R Buckingham, Samuel F Dennis Jr.

Kevin J. McGrath

Increasing Data Density with Multivariate Symbols

Daniel Huffman 